\title{
Flexible Employment Arrangements and Workplace Performance in Great Britain
}

\author{
Eleftherios Giovanis \\ Department of Economics, University of Verona, 37129 Verona, Italy; \\ giovanis95@gmail.com
}

\begin{abstract}
There is an increasing concern on the quality of jobs and productivity witnessed in the flexible employment arrangements. The aim of this study is to examine the relationship between various employment arrangements and the workplace performance. Home-based working-teleworking, flexible timing and compressed hours are the main employment types examined using the Workplace Employee Relations Survey (WERS) in years 2004 and 2011. The workplace performance is measured by two outcomes- the financial performance and labour productivity. First, the determinants of those flexible employment types are explored. Second, the ordinary least squares (OLS) method is followed. Third, an instrumental variable (IV) approach is applied to account for plausible endogeneity and to estimate the causal effects. The findings reveal a significant and positive relationship between these types of flexible employment arrangements and the workplace performance. Education, age, wage, quality of relations between managersemployees, years of experience, the area of the market the workplace is operated and the competition are significant factors and are positively associated with the propensity of the flexible employment arrangements implementation. This can have various profound policy implications for employees, employers and the society overall, including family-work balance, coping with family demands, improving the firm performance, reducing traffic congestion and stress among others. It is the first study that explores the relationship between flexible employment types and workplace performance using an IV approach. This allows us to estimate the causal effects of flexible employment types and the possible associated social implications.
\end{abstract}

Keywords: financial performance; flexible employment; labour productivity; teleworking; workplace employment relations survey

\section{Introduction}

The establishment of flexible employment programmes, as a reaction to socioeconomic, demographic and gender role changes, present an increasing popular business practice around the globe (Lähteenmaäki, 2002; Fernandez-Rios et al., 2005; Kersley et al., 2006; McNall et al., 2010). For example, Families and Work Institute in the USA reports that the number of employers offering flexible work arrangements grew from $68 \%$ in 1998 
to $81 \%$ in 2014 (Bond et al., 2005; Matos and Galinsky, 2014). We observe also a similar tendency in Europe. Plantenga and Remery (2009) showed that over $60 \%$ of employees in Europe have access to flexible working schedules. Work over the last years is disconnected from a particular place and time. This is explained by the fast boost of the information and communication technology (ICT). While the traditional place of work used to be the employer's premises, nowadays is carried out in other locations, such as the employee's home, in other remote areas or while travelling. Advances in technology reshape the relationship between work and home, where the traditional flow of employees from home to office is reversed (Bailyn, 1988). Since the 1980s, an increasing part of the workforce has been teleworking at home or in location away from employer's premises at least one day a week. This study aims to explore the effects of three main flexible employment types; the homebased working -teleworking, flexible timing and compressed hours on firm performance.

The previous literature has examined the relationship between teleworking, labour outcomes and work-family balance. But it has not explored the association between flexible employment schemes and workplace performance in Great Britain and their causal effects. Earlier studies have outlined the reasons for the growth of teleworking and other flexible employment arrangements, owned to their perceived benefits. In particular, these benefits refer to job satisfaction, productivity, organisational loyalty, improved employee morale and loyalty and savings in space office among others (Bélanger, 1999; Potter, 2003). Overall, teleworking is attracting increasing interest from researchers and policy-makers. The explanation of the flexible employment arrangement implementation, includes both consumption and production theory. It can be considered as a consumption choice when employees have alternative choices of commuting to work which can be undertaken by a variety of transportation modes. These modes have varying levels of utility for the commuter. In addition, these types of employment arrangements allow employees to cope 
with family demands, such as household domestic production and childcare. From the production side, the employer faces with various choices, such as cost reduction through reduced use of space and equipment and increase in productivity. However, the control over the labour force may be lost.

The aim of this paper is threefold. First, to explore the determinants of the abovementioned flexible employment schemes implementation. Second, to examine the effects of the flexible employment types on the workplace performance, expressed by the financial performance and labour productivity. Third, to deepen the knowledge on factors affecting performance and growth within firms and how these can be manipulated to improve the workplace performance. Understanding the effects of flexible labour schemes, not only benefits firms, but the society too. In addition, the findings can provide insights how to generate labour policies and employment schemes within economies to sustain and increase the standards of living and the general economic welfare. The analysis relies on data derived from the Workplace Employment Relations Study (WERS) in Great Britain over the years 2004 and 2011. Even though, in this study we do not examine the linkage between the specific working types, workplace performance, job satisfaction and employee loyalty, however, we suggest it for future research.

The first flexible employment arrangement explored is the teleworking and offers the choice to work from home or another place for several days a week. In the sample examined in this study, teleworking refers to those who work from home. The second employment mode explored is the flexible-timing, which refers to the ability of the employees to choose the starting and finishing time of the working day. The third option is the compressed hours and allows the employees to work four longer days and take- off the fifth day of the week.

To find the causal effects we apply the instrumental variables (IV) approach. The flexible working arrangements are instrumented with variables, such as whether the 
employee has dependent children and whether he/she takes care a disabled household member. We assume that the employees who have dependent child or taking care a disabled person are more likely to request the flexible employment types, without affecting directly the firm performance. The reason we follow the IV approach is the endogeneity issue, coming from the plausible reverse causality between the workplace performance and the flexible employment arrangements. On the one hand, it might be the case that these employment arrangements cause workplace performance. On the other hand, more productive firms may carry out these arrangements and offer them in a larger number of employees and at a higher frequency or more productive workers can choose those employment types.

The study finds a positive relationship between flexible employment, the labour productivity and firm performance. This shows that firms can apply these employment schemes resulting to plausible benefits to both employees and employers. These include cutting costs for office space, coping with the family demands, improving work-life balance, increasing the workplace performance.

The paper is organised as: Section 2 is presents a brief literature review. Section 3 presents the methodology, while in section 4 the survey and variables used in the analysis are discussed. Section 5 reports the results and section 6 presents the concluding remarks, policy implications and areas for future research.

\section{Literature Review}


In this section we present the theoretical framework within which our analysis is based. Next, we discuss previous research studies on the association between flexible employment schemes and various outcomes, such as productivity, employee loyalty and job satisfaction.

Shockley and Allen (2012) discuss two main motivations that companies offer flexible employment opportunities and the reasons the employees are likely to implement them. The first is life-management motives and the second work-related motives. Life-management motives help employees to manage both work and personal life. Studies confirm that the work-life balance management is a major motivation for employees to use flexible work arrangements. Typical examples include family demands, such as altering one's schedule to take the children to school, to go for shopping or involvement in household chores. The second category includes the work-related motives, where the flexible employment arrangements apply to increase one's productivity. For example, a person might work in an office during the hours when the office is empty or work at home listening music. Another option is to work from a remote area or at home, avoiding commuting time and dividing this extra time to family demands. Earlier studies have examined the work-related motives less often. Then, we present case studies that explored the relationship between flexible employment and productivity and their limitations. The possible drawbacks refer to cases where the studies use cross-sectional data, examine only one type of flexible employment and do not explore their causal effects on productivity.

Our empirical analysis is based on a theoretical framework where flexible working arrangements, offer job control and autonomy, improve work-family balance and job satisfaction resulting to improved productivity. The second framework refers to the boundary theory and the work-family balance which we discuss next. Researchers have pointed out the importance of having high perceptions of work control and the individual well-being. Within this framework, flexible work schedules are interventions which enable greater control to the employees, providing psychological and tangible resources to enhance 
well-being (Karasek and Theorell, 1990; Gronlund, 2007; Kelly and Moen, 2007). The job control refers to when and where people work. Kelly and Moen (2007) and Kossek et al. (2006) extend the notion of job control to manage also over how the work is done. Flexible employment schemes allow workers to have increased flexibility to cope with family demands and to integrate personal role demands with work role demands.

Flexible timing employment scheme offers the control for starting and stopping the work schedule. Within this scheme the employee can deal with non-labour demands, such as childcare, household chores and others. With compressed hours scheme, the employee can schedule non-labour activities during the scheduled fifth day-off. Using teleworking the employee can allocate the time saved from commuting to work in other activities. Overall, absenteeism is lower for the users of those flexible working arrangements due to the ability to cluster personal appointments during employee-controlled non-labour time. According to the expectancy theory developed by Vroom's (1964), individuals are more likely to be motivated to exert effort to perform for valued goals they think they can achieve. Thus, the theory assumes that people involved in the flexible working arrangements are more likely to exhibit higher performance, because they would have greater resources, including extra time and more support. This will enable employees to perceive grater expectancy they can perform both work and family roles well (Kossek et al., 2006; Kelly and Moen, 2007; Kossek and Misra, 2008). Earlier research show that employees may engage in higher extra-role performance when flexibility is available.

Lambert (2000) found that employees with access to flexible employment schemes exhibited higher organisational citizenship behaviours, productivity and loyalty. The hypothesis bolsters that flexible work schedules would lessen work-family conflict, characterised as when one role interferes with the performance of another role. Use of flexible schedules could likewise build work-family improvement, how much assets or abilities or learning in one part e.g. work, enhance the other e.g. family. This shows that 
users would have more prominent contribution in both work and family roles. Greenhaus and Powell (2006) propose that resources in one area will spill-over and affect resources in another domain prompting positive spill-over. They argue that increased flexibility provided by those employment schemes will have a positive effect on both work and family roles. Therefore, employees will have an improved well-being at home and on the job, since they will experience fewer conflicts.

This expanded positive mood in every area, thusly, will cross-exchange, and enhance the overall quality of role experiences at work and home. This belief is related to the boundary theory, and it assumes that individuals construct physical, mental and emotional fences between roles, such as work and family (Ashforth, 2001). According to Nippert- Eng (1996) the degree within which the employees prefer to fragment work and family roles varies. Flexible work schedules influence employee perceived ability to control limits amongst work and home. For example, how much the planning and area of work or family roles are flexible and penetrable (Kossek et al., 2006). Overall, the theoretical frameworks described in this section support the idea that flexible working schedules can improve productivity and performance through two channels. First, the control over the place, time and the way the job is done. Second, through the family conflict reduction and improved well-being, associate with positive spill-over effects on job.

Earlier studies found that teleworkers report an increased productivity (Bailey and Kurland, 2002; Vega et al., 2014). However, a large share of the people reported an increased number of working hours (Bailey and Kurland, 2002). Aborg et al. (2002), considering within-person effects of teleworking in two companies, found that teleworking increases work effectiveness, but this may simultaneously be result of extensive workload. So, teleworkers and flex-working employees may exhibit higher levels of job satisfaction because of the flexibility and work autonomy that these types of employment offer. This leads to extra work, resulted from the reciprocal behaviour of the flexibility offered by the 
firm. In addition, this flexibility may enable them to work harder during the hours spent at home compared to working hours at the employer's premises. The study by Patrickson (2002) explores whether teleworking offers potential employment opportunities to older people. While Patrickson (2002) finds that teleworking might appear to offer these opportunities, the take up rate is rather low. This study explores the association between teleworking and workplace performance using a sample which includes employees belonging to various age categories as suggested by Patrickson (2002). Studies in the field of organisational economics and psychology have further developed the effects of teleworking on working hours and job satisfaction. Vega et al. (2014) in a within-person study based on five consecutive working days found that employees, while they telework, are more likely to report higher levels of job satisfaction and performance. Previous studies also explored the inclination to opt teleworking, including the paper by Baruch et al. (2000). The authors using matched employees-employers samples from Hong Kong and United Kingdom found an increasing inclination to opt for teleworking in both countries.

The second employment mode explored is the flexible timing, a scheme for full time employees that allows them to choose their starting and finishing times daily. Flexible timing nowadays is considered as an important part of a work-life balance package. It intends to moderate the negative impacts of the unbending working hour culture, with results for both businesses and employees (Galinsky and Johnson, 1998). Skinner and Pocock (2011) explored the relationship between flexible timing on employment and the work-life interference using data from the 2009 Australian Work and Life Index (AWALI) survey. AWALI has information on the employment, demographic, social and work-life items and questions on employee requests for flexibility. Their findings show that women were twice as likely as men to sought flexibility. Firms granted flexible employment arrangements at almost the 20 per cent of the employees that requested them. Skinner and Pocock (2011) found that the work-life balance was better than those who did not requested 
or not fully agreed-granted the specific scheme. However, managers face challenges about flexible timing. These include the set up and maintenance of the time-keeping schedule that may lead to additional costs. This employment arrangement places a burden on the communication, supervision and scheduling of the employees' working time.

The third flexible employment type explored in this study is the compressed hours. Compressed hours is not a new idea. Molloy, director of the Human Resource (HR) at Marcel Dekker Inc. states that compressed hours improve the employee morale, enhances productivity and ultimately increases profitability (Woodward, 2000). Earlier studies show that the "compressed hours" employment scheme leads to reductions in personal leave time, sick leave and absenteeism (Hyland, et al., 2005).

Overall, previous research studies suggest that employers and governments tend to support the flexibility employment modes. They found that these practises increase the employee loyalty and productivity, reduce stress and absenteeism and improve the workfamily relation (Eaton, 2003; Halpern, 2005; Skinner and Pocock, 2011).

Green et al. (2010) examined the flexible working arrangements in 2001-2005 using the Household Income and Labour Dynamics (HILDA) survey in Australia. The authors found that the flexible working types are associated with lower perception of job security and lower payments. However, their analysis is limited to casual workers, who work temporarily having no permanent or long-term employment agreement. Therefore, we expect a negative association between casual workers and wages because of the uncertainty coming from the job insecurity and the fixed employment period.

The studies we discussed so far present various limitations. First, the sample used in every case is small and the analysis relies on cross-sectional data. Additionally, they investigate the changes on performance and productivity by the teleworking implementation, but they do not attempt a causal interpretation. Also, the studies are limited in one sector of economic activity whole the factors or controls are not adequate. For 
instance, the degree of competition that firms face from abroad or the domestic market, the market area, the type of the company and the quality of relations between employees and managers among other characteristics are not considered. This study extends the previous literature by exploring three different flexible work arrangements, and it relies on a panel data of workplaces, accounting for various factors. Additionally, we apply two stage least squares (2SLS) to explore the causal effects of those employment schemes on the firm performance. Moreover, the study uses a sample of employees with long-term contracts and not casual employees, as Green et al. (2010) examined. Therefore, this case study differs, as it considers permanent employees, who do not have a casual or temporary contract. Overall, less attention is paid in the previous literature, about the role of teleworking, flexible timing and compressed hours and their implications to the workplace performance. Furthermore, the availability and implementation of flexible work arrangements may differ according to individual characteristics of the employees, organisations and sectors. For instance, the age, education level, marital status can be important factors of propensity to carry out those employment types, but also can be significant determinants of performance. The status of the company, i.e. public or private, the competition, the area which is operated, i.e. local, regional or international, the size, the management-employee relations and the sector can be equally important factors of performance. Their investigation can offer further insights about the management in the workplace and their manipulation that may allow for improvement in productivity.

\section{Methodology}

The following equation for individual $i$, in firm $j$, location $k$ and at time $t$ is estimated: 


$$
W P_{i, j, k, t}=a_{0}+a_{1} F E_{i, j, k . t}+\alpha^{\prime} z_{i, j, k, t}+\mu_{k}+\theta_{t}+l_{j}+l_{j} T+\varepsilon_{i, j, k, t}
$$

$W P$ denotes the workplace performance. Two alternative measures of workplace performance are used in the study, financial performance and labour productivity, as we describe them in more details in the data section. The vector $F E_{i, j, k, t}$ is a dummy showing whether the respondent implements the flexible working arrangement in firm $k$, in region $j$ and in time $t . z$ is a vector of employee and firm factors, including gender, age, education, marital status, wage, quality of relations between employees-managers among others, discussed and presented in the empirical results section. Set $\mu_{k}$ denotes the workplace fixed effects, $l_{j}$ is the location fixed effects expressed by travel to work area (TTWA), $\theta_{t}$ is a time-specific vector, while $l_{j} T$ is a set of area-specific linear time trends which controls for unobservable, time-varying characteristics in the TTWA area. TTWAs are designed from the Office for National Statistics, used for the labour market analysis and planning. The areas are designed in such a way that the majority of the resident population also works within the same area. The criteria for defining and designing a TTWA is that overall at least the 75 per cent of the people who work in the area also live in the same area.

For notation convenience, individuals, workplaces, location-TTWA and time are defined in (1) as $i, k, j$ and $t$ respectively, but only the location and workplace fixed effects are considered, since the sample refers to the same workplaces but difference employees. The main purpose of the study is to explore the flexible employment types controlling for employees and firm characteristics.

The first is the flexible timing and refers to a policy in which the traditional fixed times that employees start and finish the working day are replaced by a set of rules within which employees may choose their starting and finishing times (Hicks and Klimoski, 1981; Duncan and Pettigrew, 2012). Flexible timing allows also the employee to choose how 
many hours would like to put on a specific day, while still working five days per week. The second employment scheme is the compressed hours, where employees are allowed to work ten hours per day, but four days per week (Baltes et al., 1999). As opposed to the flexible timing, compressed hours scheme is more popular to the manufacturing companies, rather than in services. The reason is that compressed workweek enables employee to follow a certain schedule, i.e work at certain allotted time, while granting a degree of flexibility, as to have three days-off instead of two. Second, opposite to services companies, employees in manufacturing sector do not have work during Monday-Friday at a specific time interval. So, it is important to control in the regressions for the sector of the workplace (Baltes et al., 1999). The third is teleworking, where employees are allowed to work at locations of their choice (Hill et al., 2001; Duncan and Pettigrew, 2012).

We follow an instrumental variable (IV) approach, because of the possible degree of reverse causality between the workplace performance and the flexible employment arrangements explored. In this case, we instrument the flexible working with the variables, such as whether the employee has dependent children, and whether the respondent handles the caring of a disabled person. These variables are not correlated with the workplace performance as the regression analysis shows. About the determinants of the flexible working arrangements we will estimate regression (1) where the dependent variable will be the dummy indicating whether the respondent implements a specific working arrangement. Since the variable is binary we apply the Logit model, while the results derived from the Probit model remain similar.

\section{Data}

The Workplace Employment Relations Study (WERS) series have started in 1980 and have taken place six times until 2011. In this study, we consider the 2004 and 2011 survey 
which took place in a random sub-sample of workplaces and it was conducted to managers and employees. The survey population for both the 2004 and 2011 WERS includes as sample of British workplaces with at least 5 employees. It comprises four main sections: the Employee Questionnaire, the Worker Representative Questionnaire, the Financial Performance Questionnaire and the Management Questionnaire. Employee Questionnaire includes information on employee characteristics while the last three provide information about the firm-establishment. This is useful for the analysis since the regressions control for both employee and workplace characteristics. In addition, the analysis of the surveys of 2004 and 2011 allow us to control for unobserved characteristics of the pre-financial crisis period and the economic shocks after 2008. We should note that we take the specific years because is a panel dataset for workplaces, but not for employees. We could have considered more years, including the surveys of 1990 and 1998, but this does not allow us to estimate the model using firm fixed effects.

We explore the relationship of the employment arrangements between two measures of workplace performance. These include the financial performance and labour productivity. The measures are derived from the Management Questionnaire and they answer in the following question "How would you assess your workplace's financial performance and labour productivity?" Then the interviewer asked the management representative to write in which of the following categories the measures fall into: a lot better than average; better than average; about average; below average or a lot below average. Thus, the measures are ordered variables ranging between 1 (very good) to 5 (very low). A negative coefficient sign, would show an improvement on the firm-workplace performance. To interpret the results easier, we recoded the measures in a way that 1 indicates very low (a lot below average) and 5 very high (a lot better than average).

One major drawback of the analysis is the reliability of the self-reported outcomes explored in the study. Earlier studies have raised this issue, especially in the economics of 
well-being. The issue is related with unobserved heterogeneity and since these measures are self-assessed on an arbitrary scale, they can suffer from differential item functioning (DIF). This makes the assumption of interpersonal comparisons potentially difficult (see Kapteyn et al., 2010 for more details). Anchoring vignettes proposed by King et al. (2004) is an alternative approach for cross-sectional data; but it is impossible with the current dataset, because the necessary information is missed. Even though the regressions account for workplace fixed effects, the answers are still given by the manager. For instance the 5 for a person $\mathrm{A}$ can be equivalent with 3 for the person $\mathrm{B}$, which makes the comparison between individuals unreliable. With the fixed effects, however, the analysis takes place within and not between managers. Since the scale of the manager's opinion does not change, this can lead to more robust estimates.

In table 1 we report the summary statistics for the main variables of interest, such as the workplace performance and the proportions of the flexible working arrangement. We observe that the average values of workplace performance are rather high in a scale 1-5 and the average values are almost 3.5. The 16 per cent of the sample is involved on teleworking, 21 on flexible timing. Almost the 27 per cent of the sample is choosing compressed hours as a working type.

The proportions of the instrumental variables are presented, because are the main variables of interest. While the 12.00 per cent of the sample has a dependent child aged $0-2$ years, almost the 70.00 per cent has a dependent child which is older than 2 years. About whether the employee is caring a disabled member the majority of the respondent answers is "no" at around 82 per cent. The 8.38 per cent is devoting $0-4$ hours per week, the 4.25 per cent spends 5-9 hours. The remained almost 5.5 per cent is caring a family members more than 9 hours per week.

In table 2 we present the correlation between the flexible employment types explored, the workplace performance, and selected control variables. A significant correlation among 
the variables of interest and other control variables used into the regressions may be present. However, since the number of controls is large, their correlation is not reported, but we discuss their association in the empirical results section. In addition, we present the candidate instrumental variables; whether the employee is caring a disabled member whether he/she has dependent child 0-2 old aged and dependent child older than 2 years old. The purpose of reporting the instrumental variables used in this study is to confirm if they are correlated with the flexible employment types and the workplace performance measures.

A positive and significant association among teleworking, compressed hours, and workplace performance measures, education, age and the instrumental variables is observed. Flexible timing is only significantly correlated to the labour productivity. Males are more likely to be older and earn more than women. Also, they are more likely to have a dependent child older than 2 years old and less likely to have a dependent child aged 0-2 years. However, as we observe in table 2 the correlation between the flexible employment schemes and wage is mixed. More specifically, while the relationship is positive and significant for teleworking, it becomes negative for compressed hours scheme. On the other hand, the relationship between the flexible timing scheme and wage is insignificant. Old aged are less likely to have a dependent child 0-2 years old. Age and the frequency of taking care a disabled member and having dependent child older than 2 years old is positive. Therefore, according to table 2 teleworking and compressed hours are instrumented with the cases where the employees care a disabled member, and having a dependent child. Flexible timing is instrumented only with the cases whether the employees have a dependent child 0-2 years old or older than 2 years old.

\section{Empirical Results}


In table 3 we present the factors that determine the propensity to implement the flexible working arrangements. The results overall show that the association among education level, teleworking and compressed hours is positive, while the relationship between wage and flexible timing is insignificant. Age and education level present a negative propensity to carry out the compressed hours. Divorced employees are more likely to follow teleworking, while married and widowed are less likely to choose the compressed hours as an employment scheme. About gender, males are more likely to choose flexible timing and compressed hours and females to choose teleworking.

Workplaces that operate in larger areas than local, face international competition and are not public are more likely to implement the flexible employment types explored in this study. Also, the results show that the quality of relations between managers and employees is an important factor of the flexible work implementation, except for compressed hours. Employees with many years of experience and the size of the workplace affect in a positive way the probability occurrence of implementing the flexible employment arrangements. Supervision of other employees has a significant and positive effect on teleworking and compressed hours. Whether the employee has a child and whether he/she cares a disabled member, the probability of implementing the flexible employment types is positive. The exception is the flexible timing as we have shown also in the correlation matrix in table 2. About the workplace type, employees in the private companies are more likely to implement those types of employment schemes, except for compressed hours, where the association is significant and negative. The results show that the competition encourages the flexible employment implementation.

The findings overall are consistent with other studies where performance-related schemes, the market area, quality of managers-employee relationships, and wage among others are significant factors for workplace performance (Hatton, 1988; Jones and Kato, 1995; Brown and Heywood, 2002). In addition, Green et al. (2010) found that employment 
types, such as casual employees are connected with low payments and low levels of job security. The analysis explores whether the flexible employment arrangements explored in this paper, are related to the workplace performance. The positive effects can be explained because employees are happy as they can cope with the household and family demands, and they may spend more time on leisure activities.

(Insert Table 3)

In table 4 we present the ordinary least squares (OLS) regression estimates. We should notice that we could have applied the ordered Probit or Logit models. However, since we follow the IV approach, we prefer the OLS to make the estimates comparable. Previous studies have applied OLS concluding that the estimates are similar (Clark and Oswald, 1996; Ahn and García, 2004; Giovanis, 2014). Another option is the "Probit OLS (POLS)" approach developed by Van Praag and Ferrer-i-Carbonnell (2006), which presents very similar estimates with those derived by OLS. This approach is useful for panel data when fixed effects models are needed since the ordered Logit and Probit models allow only for random effects estimations. Yet, the endogeneity and self-selection issues are not solved by this method.

In table 4 the results show that the association between employment schemes explored and the workplace performance measures is positive and significant. The exception is the flexible timing whose effect on financial performance is insignificant while it becomes significant and positive when we consider the labour productivity. The wage coefficients are significant and positive. Age, education and marital status have no significant effect on the measures of the workplace performance examined. An exception is the education level where those with higher degree are more likely to have a positive impact on the workplace performance. In addition, married and men who implement teleworking and flexible timing are more productive. 
The status of company and the market area that the workplace is operated are significant factors of workplace performance. According to the findings, the larger the area, the greater the performance is likely to be. The quality of relations between managers and employees and the performance-related schemes present a positive relationship with the workplace performance. The status of the workplace is significant where in the majority all the types of firms are more productive relative on the reference category which is the public firms.

Overall, so far the findings suggest that the flexible working arrangements we study here, can have benefits for the firms and their performance. Additionally, we conclude that well-educated and married people, the performance-related schemes and the quality of the management-employees relations are major factors contributing to the workplace performance. Thus, we suggest that companies should invest on any kind of flexible employment arrangements, and to quality of personnel relations. Even companies that are operated in small geographical and market area, with small number of skilled employees, can benefit from the practice of flexible employment.

In table 5 we report the 2 SLS estimates. We instrument teleworking and compressed hours with the variable on whether the employee has dependent children 0-2 years old, dependent children older than 2 years old and whether the respondent cares a disabled person in the household. For flexible timing we take as instrument the case where the respondent has a dependent child. These factors can be highly correlated with the employment types because they allow them to spend more time at home working and taking care of the children and disabled household members. As we see from the results in table 5, the causal effects of the employment types on workplace performance are confirmed. However the effects are higher than those found in table 4, by 20-60 per cent. This shows that the estimates derived by the OLS are underestimated because of the possible reverse causality we mentioned in the earlier sections. According to the weak 
instrument test, we reject the null and we conclude that the instrument variables are not weak. In addition, based on the Sargan endogeneity test, we accept the null hypothesis of no-endogeneity.

(Insert Tables 4-5)

While policies are commonly embraced at the organisational level, inside firms, there is frequently wide variety and organisational stratification in which diverse employments, work groups, and workforce demographics have access to schedules. Relatively little research has been carried out at the work group level of analysis. A review by Van Dyne et al. (2007) shows that motivation and coordinating effects of flexible schedules were the main fundamental implementation challenges at the work group level. Managers able to manage coordination of work schedules effectively are more likely to experience positive work group performance impacts. To facilitate this, is critical for the firms to allocate resources to train managers and employees to learn how to work in new scheduling forms (Lautsch and Kossek, 2009; Kossek and Hammer, 2008). Our results confirm a part of the story. As we have shown, when the relations between managers and employees is good, the employees are more likely to use the flexible employment schemes, controlling for other employee and workplace characteristics. Additionally, the quality of the relations between employee and manager is a significant factor of the firm performance. New management training and organisational culture change interventions are being designed to increase employee control over work schedules (Kossek and Hammer, 2008; Kelly and Moen, 2007). Increasing supervisor and cultural support for workplace flexibility will allow employees to have more control over work schedules, reduce work-family conflicts, and ultimately improve family well-being, and organisational productivity and performance. 
Thus, the conclusion is that these employment arrangements may be an efficient policy, especially when the employees have the option to choose their implementation, with various plausible benefits to workplace, including costs saving and improved productivity. On the other hand, the benefits for the employees, besides the plausible performance payments and other related benefits, can be job satisfaction improvement, ability to cope with their family demands, resulting to improvement of their work-family balance and their overall well-being. Additionally, it is hopeful that this research may offer insights to decision makers related to the human resource policies review to adopt and implement those flexible working arrangement as these may improve the firm performance. This may result from various factors, including employee engagement and loyalty, job satisfaction, work autonomy, work-life balance and others. Therefore, this study proposes to explore also all these interrelationships, accounting for the flexible labour schemes. Having also in mind that their implementation can be not very costly, is another motivation for the firms. Furthermore, the findings of this research are in complete accordance to those of other research studies conducted in different countries (Hatton, 1988; Jones and Kato, 1995; Woodward, 2000; Brown and Heywood, 2002; Potter, 2003; Halpern, 2005; Skinner and Pocock, 2011). The difference lies that we have used a large panel dataset over a representative sample of the complete sectors of economic activity. Also, we applied 2SLS to identify their causal effects. However, the research faces limitations in any form, due to imperfect data as a firm panel dataset and not employee. Another issue is the reliability of the outcome measures, which are self-reported answers on questions related to the financial performance and labour productivity of the workplace.

\section{Conclusions}


Flexible work arrangements for a long time have been a popular tool to manage work and life balance. The need to manage work and life obligations has become exponentially significant in the last years, following socio-economic and demographic changes between the couples. This study explored the relationship between three flexible employment arrangements and the workplace performance. The findings suggest that there is a positive effect of teleworking and compressed hours on the workplace performance while the flexible timing positively affects only the labour productivity. We confirm these results by the 2SLS. Overall, the findings indicate that the specific employment modes may have various benefits and policy implications for both employees and employers and for the society overall. On the one hand, for the employers a higher performance and productivity level may lead to profit increase and further growth. This can be reflected by increases on wages, and improvement on relations quality among the personnel in the workplace. Moreover, companies can lease a smaller number of offices and equipment resulting to cost savings. On the other hand, the benefits for the employees can be various, including relief from stress which is related to traffic congestion and commuting at work. These employment arrangements may offer more work autonomy and control of the working schedule. Furthermore, they may allow the employees to cope with the family and household demands and to devote more time on leisure activities. The latter may have additional effects on productivity through the improvement of job satisfaction and quality of life. We have not explored well-being in this study; however, we suggest it for future research. The benefits for the society include the social welfare for the employees and employers and other plausible benefits, such as the traffic and air pollution reduction and overall well-being improvement.

\section{Acknowledgments}


This work was supported by the Marie Skłodowska-Curie Individual Fellowship (IF) grant [652938-TELE]. The author gratefully acknowledges the funding provided by European Commission to carry out this research

This study used panel data from the 2004 and 2011 Workplace Employment Relations Surveys (WERS). The WERS was conducted by NatCen Social Research on behalf of the Department for Business, Innovation and Skills, the Economic and Social Research Council, the UK Commission for Employment and Skills, the Advisory, Conciliation and Arbitration Service and the National Institute of Economic and Social Research. The data was distributed by the UK Data Archive at the University of Essex.

\section{References}

Aborg, C. Fernstrom, E. and Ericson, M. (2002), "Telework - work intensification and well being. A longitudinal study. Uppsala University", Department of IT, Technical report 2002-031.

Ahn, N. and García, J.R. (2004), "Job Satisfaction in Europe”, Working Paper 2004-16. Fedea - Fundación de Estudios de Economía Aplicada.

Ashforth, B. E. (2001). Role transitions in organizations: An identity based perspective. Mahwah, N.J.: LEA Press.

Bailey, D.E. and Kurland, N.B. (2002), "A review of telework research: findings, new direction ns, and lessons for the study of modern work", Journal of Organizational Behavior, Vol. 23 No. 4, pp. 383-400.

Bailyn, L. (1988), "Freeing Work from the Constraints of Location and Time", New Technology, Work, and Employment, Vol. 3, pp. 143-152.

Baltes, B., Briggs, T.E., Huff, J.W., Wright, J.A. and Neuman, G.A. (1999). "Flexible and compressed workweek schedules: a meta-analysis of their effects on work-related criteria", Journal of Applied Psychology, Vol. 84, No. 4, pp. 496-513.

Baruch, Y., King, Y. and Yuen, J., (2000), "Inclination to opt for teleworking", International Journal of Manpower, Vol. 21, No. 7 pp. 521 - 539.

Bélanger, F. (1999), "Workers' propensity to telecommute: An empirical study", Information Management Vol. 35, No. 3, pp. 139-153.

Bond, J.T., Galinsky, E., S.S. Kim and Brownfield, E. (2005). National Study of Employers. New York: Families and Work Institute.

Brown, M. and Heywood, J.S. (2002), Paying for Performance: An International Comparison. Armonk, N.Y.: M.E. Sharpe.

Clark, A.E. and Oswald, A.J. (1996), "Satisfaction and comparison income", Journal of Public Economics, Vol. 61, No. 3, pp. 359-381.

Duncan, K.A. and Pettigrew, R.N. (2012). "The effect of work arrangements on perception of work-family balance", Community, Work \& Family, Vol. 15, No. 4, pp. 403-423.

Eaton, S.C. (2003), "If you can use them: Flexibility policies, organizational commitment and perceived performance", Industrial Relations, Vol. 42, pp. 145-167.

Fernandez-Rios, M., Rico, R., Martin, R. S. and De la Corte, L. (2005). "Spanish firms flexibility", Psicothema, Vol. 17, No. 4, pp. 620-626.

Galinsky, E. and Johnson, A. A. (1998), Reframing the Business Case for Work-Life Initiatives. New York: Families and Work Institute.

Giovanis, E. (2014), "Relationship between Well-Being and Recycling Rates: Evidence from Life Satisfaction Approach in Britain", Journal of Environmental Economics and Policy, Vol. 3, No. 2, pp. 201-214. 
Green, C. Parvinder, K. and Leeves, G. (2010), "Flexible Contract Workers in Inferior Jobs: Reappraising the Evidence", British Journal of Industrial Relations, Vol. 48, No. 3, pp. 605-629.

Greenhaus, J. H. and Powell, G. N. (2006). "When work and family are allies: A theory of work-family enrichment", Academy of Management Review, Vol. 31, pp. 72-92.

Gronlund, A. (2007). "More control, less conflict? Job demand- control, gender and workfamily conflict", Gender work and organization, Vol. 14, No. 5, pp. 476-497.

Halpern, D.F. (2005), "How Time-flexible Work Policies can Reduce Stress, Improve Health and Save Money", Stress and Health Vol. 21, pp. 157-168.

Hatton, T. (1988), "Profit-sharing in British Industry, 1865-1913", International Journal of Industrial Organization, Vol. 6, No. 1, pp. 69-90.

Hicks, W.D. and Klimoski, R.J. (1981). "The impact of flexitime on employee attitudes", Academy of Management Journal, Vol. 24, No. 2, pp. 333-341.

Hill, E.J., Hawkins, A.J., Ferris, M. and Weitzman, M. (2001). "Finding an Extra Day a Week: The Positive Influence of Perceived Job Flexibility on Work and Family Life Balance", Family Relations, Vol. 50, No. 1, pp. 49-58.

Hyland, M.M., Rowsome, C. and Rowsome, E. (2005), “The integrative effects of flexible work arrangements and preferences for segmenting or integrating work and home roles", Journal of Behavioral and Applied Management, Vol. 6, No. 2, pp. 141-160.

Jones, D.C. and Kato, T. (1995), "The productivity effects of employee stock ownership plans and bonuses: Evidence from Japanese panel data", American Economic Review, Vol. 85, No. 3, pp. 391-414.

Kapteyn, A., Smith, J. and van Soest, A. (2010). "Life satisfaction", In International Differences in Subjective Well Being, Diener, E., Helliwell, J. E. and Kahneman, D. Eds. Oxford University Press, Oxford.

Karasek, R. A. and Theorell, T. (1990). Healthy work: Stress, productivity, and the reconstruction of working life. New York: Basic Books.

Kelly, E. L. and Moen, P. (2007). "Rethinking the Clockwork of Work: Why Schedule Control May Pay Off at work and at home", Advances in Developing Human Resources, Special Issue on Work-Life Integration., Vol. 11, No. 9, pp. 487-506.

Kersley, B., Alpin, C., Forth, J., Bryson, A., Bewley, H., Dix, G. and Oxenbridge, S. 2006. Inside the Workplace: finding from the 2004 Workplace employment Relations Survey. London: Routledge.

King, G., Murray, C.J.L., Salomon, J.A. and Tandon, A. (2004). "Enhancing the Validity and Cross-cultural Comparability of Measurement in Survey Research", American Political Science Review, Vol. 98, No. 1, pp. 191-207.

Kossek, E. E., Lautsch, B.A. and Eaton S.C. (2006). "Telecommuting, control, and boundary management: Correlates of policy use and practice, job control, and workfamily effectiveness", Journal of Vocational Behavior, Vol. 68, pp. 347-367.

Kossek, E. and Hammer, L. (2008). "Work/Life training for supervisors gets big results", Harvard Business Review. pp, 36.

Kossek, E. and K. Misra (2008). Nonwork influences on work motivation. In Work motivation: Past, Present, and Future. SIOP Frontiers Volume In Kanfer, R., Chen, G. and Pritchard R. (Eds). LEA Press: Erlbaum, pp. 471- 500.

Lähteenmaäki, S. (2002). "Flexible Working in Finland - Sign of New IR or Just the Opposite?" In I.U. Zeytinoglu (Ed.), Flexible Work Arrangements: Conceptualizations and International Experiences: 221-239. The Hage: Kluwer Law International.

Lambert, S. (2000). "Added benefits: The link between work-life benefits and organizational citizenship behaviour", Academy of Management Journal, 801-815. 
Lautsch, B. and Kossek, E. (2009). "Supervisor paradoxes of managing telecommuting", Human Relations. Vol. 62, No. 6, pp. 795-827.

Matos, K. and Galinsky, E. (2014) National Study of Employers. New York: Families and Work Institute.

Mcnall, L.A., Masuda, A.D. and Nicklin, J.M. (2010). "Flexible work arrangements, job satisfaction, and turnover intentions: the mediating role of work-to-family enrichment", The Journal of Psychology, Vol. 144, No. 1, pp. 61-81.

Nippert-Eng, C. (1996). Home and work: Negotiating boundaries through everyday life. Chicago: University of Chicago Press.

Patrickson, M. (2002), "Teleworking: potential employment opportunities for older workers?", International Journal of Manpower, Vol. 23, No. 8, pp. 704 - 715.

Plantenga, J. and Remery, C. (2009). Flexible working time arrangements and gender equality: A comparative review of 30 countries. European Commission, DirectorateGeneral for Employment, Social Affairs and Equal Opportunities.

Potter, E.E. (2003), "Telecommuting: The future of work, corporate culture, and American society", Journal of Labor Research, Vol. 23, No. 1, pp. 73-83.

Shockley, K.M. and Allen, T.D. (2012). 'Motives for flexible work arrangement use', Community, Work \& Family, Vol. 15, No. 2, pp. 217-231.

Skinner, N. and Pocock, B. (2011), "Flexibility and Work-Life Interference in Australia", Journal of Industrial Relations, Vol. 53, No. 1, pp. 65-82.

Van Dyne. L., Kossek, E. and Lobel S. (2007). "Less Need to Be There: Cross Level Effects of Work Practices that support Work-Life Flexibility and Enhance Group Processes and Group-Level OCB”, Human Relations, Vol. 60, No. 8, pp. 1123- 1153.

Van Praag, B.M.S. and Ferrer-i-Carbonell, A. (2006), "An almost integration-free approach to ordered response models". Tinbergen Institute Discussion Paper No. 2006-047/3.

Vega, R.P. Anderson, A.J. and Kaplan, S.A. (2014), "A within-person examination of the effects of telework", Journal of Business and Psychology, Vol. 30, No. 2, pp. 313-323.

Vroom, V. (1964). Work and motivation. NY: Wiley

Woodward, N.H. (2000). TGI Thursday. http://www.shrm.org/publications/hrmagazine/ EditorialContent/0700/ Pages/0700woodward.aspx

(C) 2017 by the author; licensee Preprints, Basel, Switzerland. This article is an open access article distributed under the terms and conditions of the Creative Commons by Attribution (CC-BY) license (http://creativecommons.org/licenses/by/4.0/). 
Table 1. Summary Statistics

\begin{tabular}{|c|c|c|c|c|c|}
\hline Variable & Mean & $\begin{array}{l}\text { Standard } \\
\text { deviation }\end{array}$ & Minimum & Maximum & \\
\hline & \multicolumn{5}{|c|}{ Panel A: Ordered variables } \\
\hline Financial Performance & 3.525 & 0.848 & 1 & 5 & \\
\hline \multirow[t]{2}{*}{ Labour Productivity } & 3.512 & 0.728 & 1 & 5 & \\
\hline & \multicolumn{5}{|c|}{ Panel B: Categorical variables } \\
\hline & Yes & No & & Yes & No \\
\hline $\begin{array}{l}\text { Teleworking-Home } \\
\text { Based Working }\end{array}$ & 16.46 & 83.54 & Compressed Hours & 27.56 & 72.44 \\
\hline Flexible Timing & 21.51 & 78.49 & $\begin{array}{l}\text { Dependent child } 0- \\
2 \text { years old }\end{array}$ & 12.36 & 87.64 \\
\hline $\begin{array}{c}\text { Dependent child }>2 \\
\text { years old }\end{array}$ & 70.54 & 29.46 & $\begin{array}{l}\text { Care disabled } \\
\text { member }\end{array}$ & $82.10(\mathrm{No})$ & $\begin{array}{c}8.38(0-4 \text { hours } \\
\text { per week) }\end{array}$ \\
\hline Care disabled member & $\begin{array}{l}4.25 \text { (5-9 hours } \\
\text { per week) }\end{array}$ & $\begin{array}{c}2.06(10-19 \\
\text { hours per week) }\end{array}$ & $\begin{array}{l}\text { Care disabled } \\
\text { member }\end{array}$ & $\begin{array}{c}1.01(20-34 \\
\text { hours per week) }\end{array}$ & $\begin{array}{c}2.22(>34 \\
\text { hours per } \\
\text { week) }\end{array}$ \\
\hline
\end{tabular}


Table 2. Correlation matrix

\begin{tabular}{|c|c|c|c|c|c|c|c|c|c|c|c|}
\hline & $\begin{array}{c}\text { Financial } \\
\text { Performance }\end{array}$ & $\begin{array}{c}\text { Labour } \\
\text { productivity }\end{array}$ & Telework & $\begin{array}{l}\text { Flexible } \\
\text { Timing }\end{array}$ & $\begin{array}{l}\text { Compressed } \\
\text { Hours }\end{array}$ & $\begin{array}{l}\text { Gender } \\
\text { (Male) }\end{array}$ & Age & Wage & Education & $\begin{array}{l}\text { Caring } \\
\text { disabled }\end{array}$ & $\begin{array}{l}\text { Dependent } \\
\text { child } 0-2 \\
\text { aged }\end{array}$ \\
\hline $\begin{array}{l}\text { Labour } \\
\text { productivity }\end{array}$ & $\begin{array}{c}0.4604 * * * \\
(0.0000)\end{array}$ & & & & & & & & & & \\
\hline Telework & $\begin{array}{c}0.0211^{* * * *} \\
(0.0002)\end{array}$ & $\begin{array}{l}0.0294 * * \\
(0.0342)\end{array}$ & & & & & & & & & \\
\hline $\begin{array}{l}\text { Flexible } \\
\text { Timing }\end{array}$ & $\begin{array}{c}0.0038 \\
(0.3432) \\
\end{array}$ & $\begin{array}{c}0.0226^{* * *} \\
(0.0001)\end{array}$ & $\begin{array}{c}0.3020 * * * \\
(0.0000)\end{array}$ & & & & & & & & \\
\hline $\begin{array}{l}\text { Compressed } \\
\text { Hours }\end{array}$ & $\begin{array}{c}0.0202 * * * \\
(0.0008)\end{array}$ & $\begin{array}{l}0.0109^{*} \\
(0.0662)\end{array}$ & $\begin{array}{c}0.1095 * * * \\
(0.0000)\end{array}$ & $\begin{array}{c}0.3059 * * * \\
(0.0000)\end{array}$ & & & & & & & \\
\hline $\begin{array}{l}\text { Gender } \\
\text { (Male) }\end{array}$ & $\begin{array}{c}0.0008 \\
(0.8646) \\
\end{array}$ & $\begin{array}{c}-0.0137 * * * \\
(0.0031) \\
\end{array}$ & $\begin{array}{c}-0.0476 * * * \\
(0.0000) \\
\end{array}$ & $\begin{array}{c}0.0611^{* * * *} \\
(0.000)\end{array}$ & $\begin{array}{c}0.1133 * * * \\
(0.0000)\end{array}$ & & & & & & \\
\hline Age & $\begin{array}{c}-0.0280 * * * \\
(0.0000)\end{array}$ & $\begin{array}{c}-0.0218^{* * * *} \\
(0.0000)\end{array}$ & $\begin{array}{c}0.0229 * * * \\
(0.0000)\end{array}$ & $\begin{array}{c}0.0587 * * * \\
(0.0021)\end{array}$ & $\begin{array}{c}-0.1283 * * * \\
(0.0000)\end{array}$ & $\begin{array}{c}0.0340 * * * \\
(0.0000)\end{array}$ & & & & & \\
\hline Wage & $\begin{array}{l}0.0032 * \\
(0.0518)\end{array}$ & $\begin{array}{l}0.0081^{*} \\
(0.0925)\end{array}$ & $\begin{array}{c}0.3244 * * * \\
(0.0000)\end{array}$ & $\begin{array}{c}0.0516 \\
(0.2911)\end{array}$ & $\begin{array}{c}-0.1309 * * * \\
(0.0000)\end{array}$ & $\begin{array}{c}0.3322 * * * \\
(0.0000)\end{array}$ & $\begin{array}{c}0.1187 * * * \\
(0.0000)\end{array}$ & & & & \\
\hline Education & $\begin{array}{c}0.0262^{* * *} \\
(0.0000)\end{array}$ & $\begin{array}{c}0.0195 * * * \\
(0.0001)\end{array}$ & $\begin{array}{c}0.2057 * * * \\
(0.0000) \\
\end{array}$ & $\begin{array}{c}0.0220 * * * \\
(0.0003)\end{array}$ & $\begin{array}{c}0.0386 \\
(0.7822) \\
\end{array}$ & $\begin{array}{c}-0.0010 \\
(0.08367) \\
\end{array}$ & $\begin{array}{l}-0.0002 \\
(0.9674) \\
\end{array}$ & $\begin{array}{c}0.2232 * * * \\
(0.0000) \\
\end{array}$ & & & \\
\hline $\begin{array}{l}\text { Caring } \\
\text { disabled }\end{array}$ & $\begin{array}{l}-0.0046 \\
(0.3284)\end{array}$ & $\begin{array}{c}0.0122 \\
(0.1013)\end{array}$ & $\begin{array}{c}0.0415^{* * * *} \\
(0.0000)\end{array}$ & $\begin{array}{l}-0.0027 \\
(0.6168)\end{array}$ & $\begin{array}{c}0.0295 * * * \\
(0.0007)\end{array}$ & $\begin{array}{c}-0.0503 * * * \\
(0.0000)\end{array}$ & $\begin{array}{c}0.1523 * * * \\
(0.0000)\end{array}$ & $\begin{array}{c}-0.0626^{* * *} * \\
(0.0000)\end{array}$ & $\begin{array}{c}-0.0369 * * * \\
(0.0000)\end{array}$ & & \\
\hline $\begin{array}{l}\text { Dependent } \\
\text { child } 0-2 \text { aged }\end{array}$ & $\begin{array}{c}0.0011 \\
(0.8935) \\
\end{array}$ & $\begin{array}{c}0.0104 \\
(0.1913) \\
\end{array}$ & $\begin{array}{c}0.0369^{* * * *} \\
(0.0000)\end{array}$ & $\begin{array}{c}0.0139 * * \\
(0.0380)\end{array}$ & $\begin{array}{c}0.0380 * * * \\
(0.0000)\end{array}$ & $\begin{array}{c}-0.0596^{* * * *} \\
(0.0000) \\
\end{array}$ & $\begin{array}{c}-0.1752 * * * \\
(0.0000)\end{array}$ & $\begin{array}{c}0.0482 * * * \\
(0.0000)\end{array}$ & $\begin{array}{c}0.0530 * * * \\
(0.0000)\end{array}$ & $\begin{array}{c}-0.0608 * * * \\
(0.0000)\end{array}$ & \\
\hline $\begin{array}{l}\text { Dependent } \\
\text { child }\end{array}$ & $\begin{array}{c}0.0072 \\
(0.1291) \\
\end{array}$ & $\begin{array}{l}0.0232 * * \\
(0.0284) \\
\end{array}$ & $\begin{array}{c}0.0318^{* * * *} \\
(0.0046)\end{array}$ & $\begin{array}{c}0.1146^{* * * *} \\
(0.0000)\end{array}$ & $\begin{array}{c}0.2896^{* * *} \\
(0.0000)\end{array}$ & $\begin{array}{c}0.0428^{* * * *} \\
(0.000)\end{array}$ & $\begin{array}{c}0.0824 * * * \\
(0.0000)\end{array}$ & $\begin{array}{c}-0.0229 * * * \\
(0.000)\end{array}$ & $\begin{array}{c}0.0287 * * * \\
(0.0000) \\
\end{array}$ & $\begin{array}{c}0.0246^{* * * *} \\
(0.0000)\end{array}$ & $\begin{array}{c}-0.1156^{* * * *} \\
(0.0000)\end{array}$ \\
\hline
\end{tabular}

P-values in parentheses, ${ }^{* * *} \mathrm{p}<0.01,{ }^{* *} \mathrm{p}<0.05,{ }^{*} \mathrm{p}<0.1$ 
Table 3. Determinants of the Flexible Employment Arrangements

\section{VARIABLES}

Wage (reference $=£ 141-£ 180$ per week)

Wage - £181-£220 per week

Wage - £221-£260 per week

Wage - £261-£310 per week

Wage - £311-£360

Wage -£361-£430

Wage - £431-£540 per week

Wage - £541-£680

Wage - $£ 681-£ 870$ per week

Wage - $£ 871$ or more per week

Gender (Male)

Age (reference category=16-17 years old)

Age (18-19)

Age (20-21)

Age (22-20)

Age (30-30)

Age (40-49)

Age (50-59)

Age (60-64)
(1)

(2)

(3)

DV: Flexible Timing DV: Compressed Hours DV: Teleworking

\begin{tabular}{|c|c|c|}
\hline 0.2254 & 0.0640 & 0.2259 \\
\hline$(0.1597)$ & $(0.1718)$ & $(0.2779)$ \\
\hline 0.0632 & 0.0934 & -0.1007 \\
\hline$(0.1559)$ & $(0.1703)$ & $(0.2862)$ \\
\hline-0.1285 & 0.1478 & $-0.4984^{*}$ \\
\hline$(0.1536)$ & $(0.1677)$ & $(0.3000)$ \\
\hline-0.1252 & -0.0582 & -0.0509 \\
\hline$(0.1484)$ & $(0.1613)$ & $(0.2724)$ \\
\hline-0.1882 & $0.2818^{*}$ & 0.0429 \\
\hline$(0.1447)$ & $(0.1563)$ & $(0.2614)$ \\
\hline-0.0562 & $0.9328 * * *$ & $0.6671 * * *$ \\
\hline$(0.1422)$ & $(0.1575)$ & $(0.2469)$ \\
\hline-0.0140 & $0.8803 * * *$ & $1.2914 * * *$ \\
\hline$(0.1445)$ & $(0.1600)$ & $(0.2445)$ \\
\hline-0.0309 & $1.0077 * * *$ & $1.9099 * * *$ \\
\hline$(0.1492)$ & $(0.1675)$ & $(0.2464)$ \\
\hline 0.0913 & $1.0588 * * *$ & $2.3658 * * *$ \\
\hline (0.1589) & $(0.1823)$ & $(0.2536)$ \\
\hline $0.4206^{* * *}$ & $0.5600 * * *$ & $-0.4953 * * *$ \\
\hline$(0.0427)$ & $(0.0483)$ & $(0.0619)$ \\
\hline 0.0856 & 0.0272 & -0.0730 \\
\hline$(0.2301)$ & $(0.2328)$ & $(0.4971)$ \\
\hline-0.2008 & -0.0366 & 0.0946 \\
\hline$(0.2249)$ & $(0.2291)$ & $(0.4563)$ \\
\hline $0.4640 * *$ & $-0.3891 *$ & 0.4861 \\
\hline$(0.2012)$ & $(0.2048)$ & $(0.3985)$ \\
\hline $0.7998 * * *$ & $-0.4412^{* *}$ & $0.6642 *$ \\
\hline$(0.2015)$ & $(0.2052)$ & $(0.3966)$ \\
\hline $0.8025 * * *$ & $-0.7422 * * *$ & 0.4151 \\
\hline$(0.2029)$ & $(0.2069)$ & $(0.3984)$ \\
\hline $0.7283 * * *$ & $-0.8931 * * *$ & 0.4005 \\
\hline$(0.2039)$ & $(0.2083)$ & $(0.3995)$ \\
\hline 0.3653 & -0.4108 & $1.3263 * * *$ \\
\hline
\end{tabular}


Marital Status (reference $=$ Single)

(0.2991)

$(0.3057)$

$(0.4868)$

Marital status-Married or couple

$\begin{array}{ccc}-0.0392 & -0.2486^{*} & 0.0904 \\ (0.1129) & (0.1354) & (0.1644) \\ -0.0878 & -0.0537 & 0.0919 \\ (0.0861) & (0.0957) & (0.1274) \\ -0.0343 & -0.1771^{* * *} & 0.1746^{* *} \\ (0.0587) & (0.0638) & (0.0858)\end{array}$

Education level (reference $=$ primary school)

Education level- A-AS levels

$-0.0919 * *$

$(0.0412)$

$0.2505^{* * *}$

$(0.0507)$

Education level-Higher degree

$0.2468 * * *$

(0.0802)

$0.5717 * *$

Dependent Chidden 0-2 years old

$(0.2315)$

$0.2221 * * *$

$(0.0520)$

$0.0054^{*}$

(0.0031)

$\begin{array}{cc}-0.1220 * * * & 0.1032 * \\ (0.0468) & (0.0591) \\ -0.0093 & 0.5505 * * * \\ (0.0616) & (0.0633) \\ -0.0147 & 0.7294 * * * \\ (0.1013) & (0.0897) \\ 0.3493 * & 0.4524 * * \\ (0.1833) & (0.2200) \\ 0.2553 * * * & 0.2632 * * \\ (0.0583) & (0.1237) \\ 0.0093 * * * & 0.0083 * \\ (0.0035) & (0.0047)\end{array}$

Table 3 (cont) Determinants of the Flex

$\begin{array}{r}\text { Table } 3 \\ \hline \text { VARIABLES }\end{array}$

(1)

(2)

(3)

Supervise others (No)

DV: Flexible T
-0.0590
$(0.0422)$

$0.0001 * * *$

pressed Hours

eleworking

Total Employees

Care Disabled Member $($ reference $=\mathrm{No})$

Care Disabled Member (0-4 hours per week)

$(0.00003)$

$-0.1029 * *$

(0.0489)

$0.0001 * * *$

$-0.0754 * *$

(0.0372)

$-0.00002$

0.0744

$(0.00002)$

$(0.00003)$

Care Disabled Member (5-9 hours per week)

$(0.0723)$

0.0480

$-0.0977$

$-0.1158$

(0.0860)

(0.1035)

$(0.1016)$

$-0.1629$

$0.2651^{*}$

$-0.1037$

$(0.1186)$

$(0.1579)$

Care Disabled Member (10-19 hours per week)

$(0.1327)$

0.3033

0.0055
$(0.1569)$

$-0.2626$

Care Disabled Member (20-34 hours per week)

$0.1637 * *$

(0.2272)

(0.2745)

(0.0811)

Care Disabled Member ( $>34$ hours per week)

0.0390

$0.1813^{* *}$

$(0.1087)$

$0.2144 * *$ 
Quality of relations-Neither good nor bad

Quality of relations-Poor

Quality of relations-Neither good nor bad

Quality of relations-Good

Quality of relations-Very Good

Market Area (reference $=$ Local)

Market Area-Regional

Market Area-National

Market Area-International

Competition from abroad (reference $=$ yes a lot)

Competition from abroad-Little

Competition from abroad-No

Competition from domestic market (reference=yes a lot)

Competition from domestic market -Little

Competition from domestic market - No

Company Status (reference Public)

Company- Private Limited Company

Company- Limited by guarantee

Company- Partnership

Company- Co-operative

Government-owned limited company

Observations
(0.1337)

(0.0839)

(0.1021)

$0.2146^{* * *}$

(0.0414)

$0.2143 * * *$

$(0.0712)$

$1.0547 * * *$

(0.1864)

$1.1149 *$

(0.6553)

$0.1122 *$

(0.0608)

$0.1515^{* * *}$

$(0.0501)$

0.1122 *

(0.0630)

$-0.0609$

$(0.0649)$

0.0544

(0.0577)

$-0.3940 * * *$

(0.0742)

$-0.3542 * * *$

(0.0731)

0.0675

(0.0731)

$0.2735^{* * *}$

$(0.0961)$

$-0.1303$

(0.0830)

0.1020

(0.0767)

0.2360 *

(0.1347)

12,837
$0.1058 * *$

(0.0476)

$-0.1016$

$(0.0828)$

$-0.2677$

(0.1862)

$-0.5528$

(0.6056)

$0.1791 * * *$

(0.0690)

$-0.0620$

$(0.0569)$

$0.2404 * * *$

(0.0726)

0.0711

(0.0766)

$-0.1379 * *$

(0.0666)

0.1180

(0.0890)

$0.2139 * *$

(0.0876)

$-0.5594 * * *$

(0.1236)

$-0.1056$

$(0.0927)$

$-0.1751^{*}$

(0.0901)

$-0.3514 * * *$

(0.1637)

0.1967

$(0.1701)$

11,400
$0.2420 * * *$

(0.0582)

$0.5220 * * *$

(0.1064)

$-0.0548$

(0.2182)

$-0.0998$

(0.8374)

$0.3320 * * *$

(0.0881)

$0.2737 * * *$

(0.0740)

0.1444

(0.0911)

0.0350

(0.0889)

$-0.1519 *$

(0.0801)

$-0.3719 * * *$

(0.1008)

$-0.2231 * *$

(0.0987)

$0.3754 * * *$

(0.0663)

$0.9268 * * *$

(0.1248)

$0.2875^{* *}$

(0.1233)

$0.5563 * * *$

(0.1286)

$0.9300 * * *$

(0.1647)

14,046 


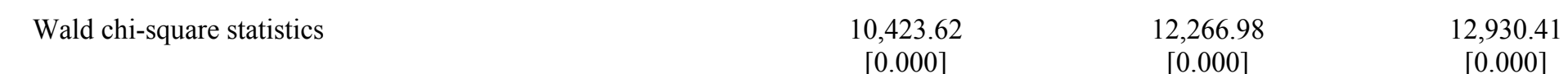

Robust standard errors in parentheses, P-values within brackets, ${ }^{* * *} \mathrm{p}<0.01, * * \mathrm{p}<0.05, * \mathrm{p}<0.1$

Table 4. OLS for the Flexible Employment Arrangements and Workplace Performance

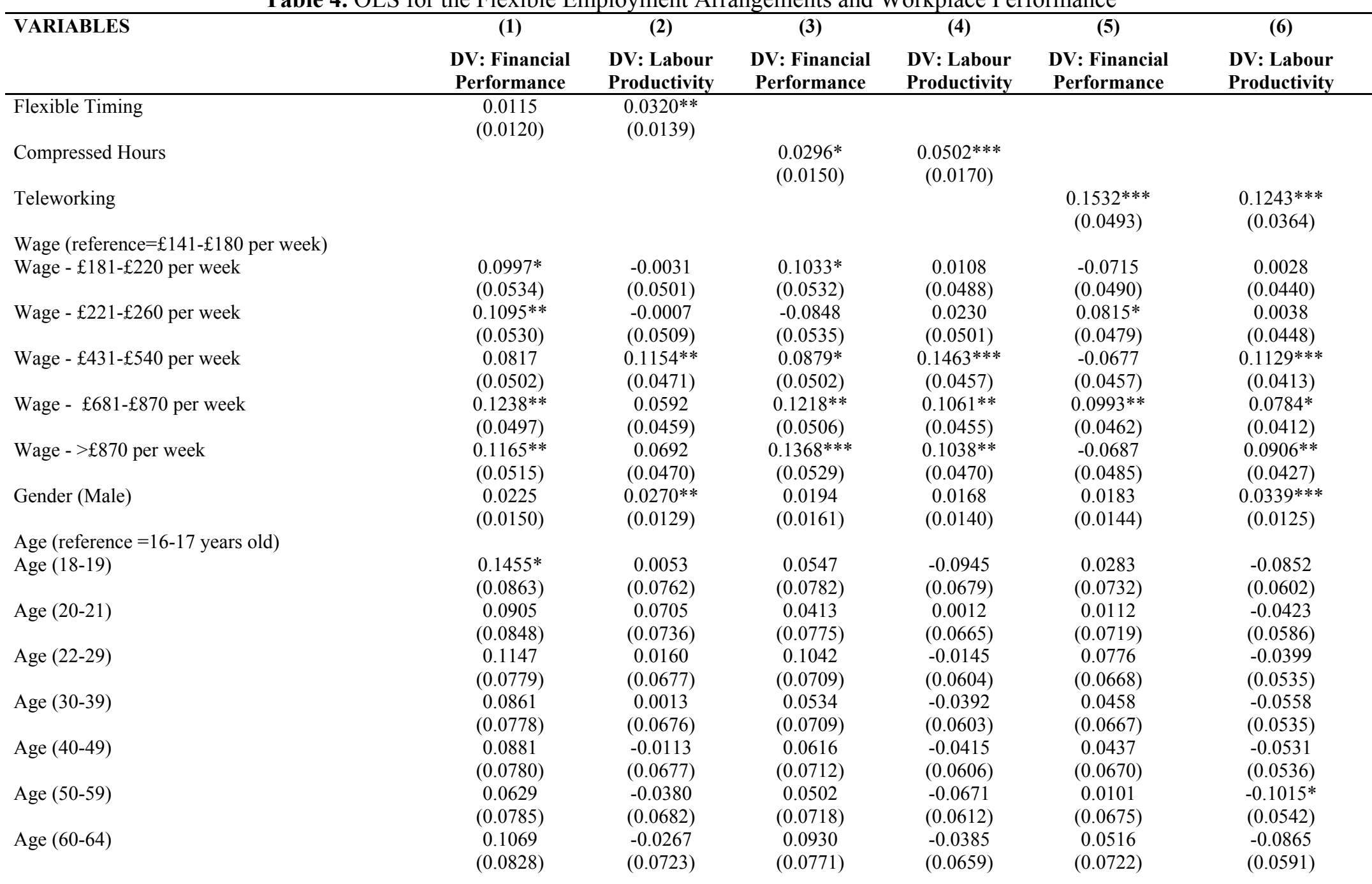


Marital Status (reference=Single)

Marital status-Married or couple

Marital status-Divorced

0.0277

$0.0861 * *$

(0.0240)

$(0.0226)$

$(0.0195)$

0.0028

0.0390

$(0.0297)$

$-0.0156$

$-0.0181$

$(0.0319)$

Marital status-Widowed

Education level $($ reference $=$ primary school $)$

Education level- A-AS levels

$-0.0110$

$(0.0192)$

(0.0234)

$(0.0207)$

$-0.0327$

$(0.0271)$

$-0.0198$

(0.0204)

0.0063

$(0.0146)$

$-0.0091$

$-0.0104$

$(0.0128)$

$-0.0114$

0.0095

(0.0182)

$(0.0151)$

$(0.0280)$

$0.0419^{*}$

Education level-Higher degree

Years of experience

$0.0032 * * *$

$(0.0227)$

$0.0038 * * *$

$0.00001 * *$

(0.0011)

(0.00002)

$(0.00002)$

$(0.0153)$

$-0.0167$

(0.0198)

$0.0421^{*}$

$(0.0217)$

$0.0055 * * *$

$(0.0013)$

Total Employees

Company Status (reference Public)

Company- Private Limited

Company- Limited by guarantee

$\begin{array}{ccc}0.0680 * * * & 0.1079 * * * & 0.0562 * * * \\ (0.0170) & (0.0143) & (0.0178) \\ 0.1254 * * * & -0.1030^{* * *} & 0.1278^{* * *} \\ (0.0332) & (0.0362) & (0.0371)\end{array}$

$-0.0181$

$(0.0136)$

0.0126

(0.0167)

$0.0358 *$

$(0.0177)$

$0.0056 * * *$

(0.0012)

0.00002

$(0.00004)$

$(0.0214)$
0.0350

$-0.0137$

$(0.0243)$

$(0.0282)$

$-0.0183$

$(0.0213) \quad(0.0184)$

$-0.0084$

$-0.0115$

$(0.0139) \quad(0.0122)$

$\begin{array}{ll}-0.0172 & 0.0032\end{array}$

$(0.0179) \quad(0.0148)$

$0.0265^{*}$

$(0.0182) \quad(0.0128)$

$0.0036 * * * \quad 0.0042 * * *$

$(0.0012) \quad(0.0010)$

$0.00001^{* * *} \quad 0.00001^{* * *}$

$(0.00002) \quad(0.00001)$

$0.1026 * * *$

$(0.0152)$

$0.0540 * * * \quad 0.1060 * * *$

$\begin{array}{lll}-0.0733^{*} & 0.1144 * * * & -0.0516\end{array}$

$(0.0410)$

(0.0331)

$(0.0361)$

Table 4 (cont.) OLS for the Flexible Employment Arrangements and Workplace Performance

VARIABLES

(2)

(5)

DV: Financial DV: Labour

DV: Financia

DV: Labour

DV: Financial

Productivity Performance

DV: Labour

Performance

$0.0630 * *$

$0.1269^{* * *}$

0.0497*

$0.1522 * * *$

Productivity

$(0.0292)-(0.0272)$

(0.0274)

$0.0715^{* * *}$

$(0.0309)$
$0.0501 *$

$0.1688^{* * * *}$

$0.0831 * * *$

(0.0264)

(0.0266)

(0.0227)

(0.0285)

(0.0242)

(0.0254)

$0.1752 * * *$
$(0.0213)$

Performance related payments

$(0.0125)$

$(0.0152)$

$(0.0135)$

$(0.0137)$

0.0186

Market Area (reference=Local)

Market Area-Regional

$0.1314 * * *$

$0.0750 * * *$

$(0.0215)$

(0.0183)

$0.1129 * * *$

$0.0736^{* * *}$

(0.0137)

$(0.0121)$

Market Area-National

$0.1204 * * *$

$(0.0226)$

(0.0194)

$0.1484 * * *$

$0.0603 * * *$

$(0.0179)$

(0.0163)

Market Area-International

$0.1012 * *$

$0.1904^{* * *}$

$0.0422^{* *}$

$0.1269 * * *$

(0.0205)

$(0.0175)$

(0.0193)

$0.0405^{* *}$

(0.0175***

(0.0221)

(0.0199)

(0.0233)

$0.1881 * *$

$(0.0172)$

$(0.0156)$

(0.0212)

(0.0210)

$0.1902 * * *$

(0.0191)

Competition from abroad (reference=yes a lot) 


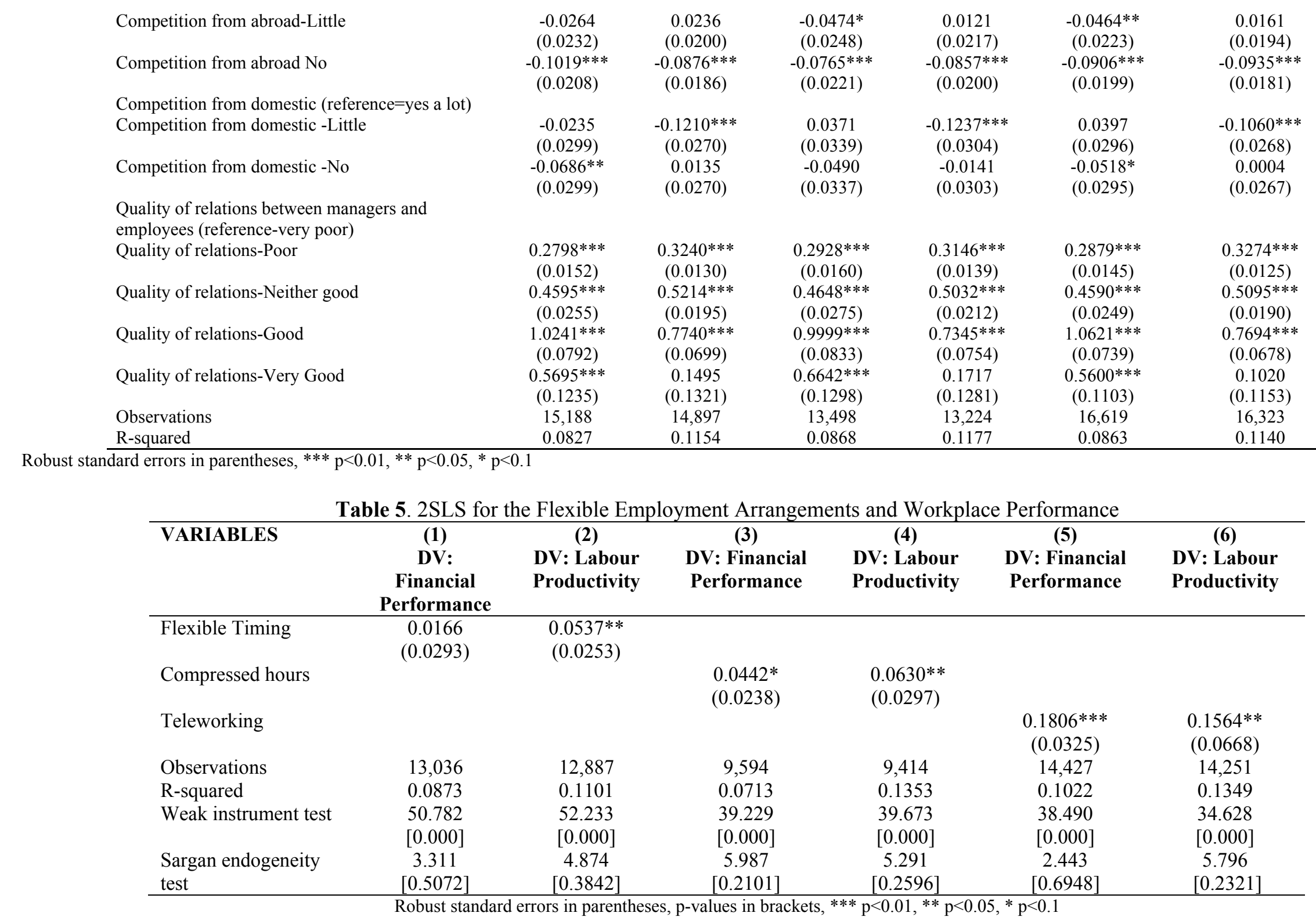

